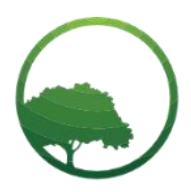

Research in Business \& Social Science

\title{
Building empowerment model of cocoa oil small-sized industries to increase value added
}

\author{
Sudirman Zaid@(a), La Hatani(b), Hayat Yusuf(c) \\ $(a, b, c)$ Faculty of Economics and Business, Halu Oleo University, Indonesia
}

Crossref

\begin{tabular}{l} 
A R T I C L E I N F O \\
\hline Article history: \\
Received 12 May 20 \\
Received in revised form 05 June 20 \\
Accepted 12 June 20 \\
\hline Keywords: \\
Empowerment; Model Design; Cocoa \\
Oil Small-sized Industries \\
\hline JEL Classification: \\
M21
\end{tabular}

\begin{abstract}
A B S T R A C T
This study aims to explore the problems faced by cocoa oil small-sized industries and develop an empowerment model design from the perspective of business management to increase added value implemented in the Agropolitan Region in the Province of Southeast Sulawesi, Indonesia. This study uses a qualitative approach, where data analysis is performed using the Nvivo 12 Plus software. Exploration results show that the perspective of business management which is a problem in the development of cocoa oil small-sized industries is the supply of raw materials; price of raw materials; variable cost; machine capacity; human resources; capital; institutional; product price; market access; assets legality; and partnership. The results of the design of the empowerment model explained that there was a need for a partnership between cocoa oil small-sized industries and other related parties such as; supplier of raw materials and target markets so that this empowerment effort can go well; and it is hoped that there will be government support in managerial aspects, both physical and non-physical so that cocoa oil small-sized industries can increase the added value.
\end{abstract}

() 2020 by the authors. Licensee SSBFNET, Istanbul, Turkey. This article is an open access article distributed under the terms and conditions of the Creative Commons Attribution (CC BY) license (http://creativecommons.org/licenses/by/4.0/).

\section{Introduction}

The enactment of economic and political decentralization regulations requires regions in Indonesia to be able to manage all economic potentials in their regions to build comparative and regional competitive advantages which will then be directed to create added value and improve the welfare of their communities. One of the steps taken by the regions in anticipating these regulations is to develop regional industrial businesses in the effort to create economic added value. Developed industries are industries based on local core competencies which are the basis in creating comparative advantage.

One commodity that is widely produced by regions in Indonesia which are also local core competencies is cocoa. Cocoa is a leading commodity which is an export-based commodity. Objective conditions indicate that the majority of Indonesia's cocoa commodity production is exported in logs. But this is seen as less effective because it is unable to create economic added value. For this reason, in the context of creating added value, processing industries are developed that aim to process cocoa commodities to become semifinished products, such as cocoa oil, and finished products, such as chocolate bars or cocoa powder.

Cocoa oil is a processed product of cocoa beans which is an intermediate product and is a raw material in making various types of food products, such as; chocolate bars or chocolate paste, margarines, and non-food products, such as; bath soap (Fahrozi et al, 2018). The cocoa oil industry is an export-based industry that is expected to be able to create economic added value for the industrial community. In Indonesia, especially in Southeast Sulawesi Province, the cocoa oil industry is an industry based on small-sized industries which is quite much sought after by the community. There are two fairly large areas which are the basis of cocoa oil smallsized industries in Southeast Sulawesi, namely; Lanipa Valley Agropolitan Area in North Kolaka Regency, and Rawa Tinondo Agropolitan Area in East Kolaka Regency (Zaid, 2016). Economically, the development of cocoa oil small-sized industries aims to increase added value, open employment, and is expected to increase people's income. Empirical conditions indicate that the two regions are the largest cocoa producing regions in Southeast Sulawesi. The cocoa beans produced in the region are export-based

* Corresponding author. ORCID ID: 0000-0002-5977-5623

(C) 2020 by the authors. Hosting by SSBFNET. Peer review under responsibility of Center for Strategic Studies in Business and Finance. https://doi.org/10.20525/ijrbs.v9i4.727 
commodities. Related to the high quantity of cocoa beans produced, the Southeast Sulawesi provincial government in 2010 issued a regulation related to efforts to increase the added value of cocoa commodities through the development of a community-based cocoa oil industry (Zaid, 2016). This is intended so that the community around the agropolitan area will gain added value. However, a few years after the application of the regulation, the existence of cocoa oil small-sized industries has not provided the expected results (Zaid et al, 2017). The standard of living of the people in the agropolitan area has not experienced a significant increase. This can be seen from the level of economic growth and the income per capita of the people in that area has not experienced an increase (BPS Southeast Sulawesi, 2019), so that as a result many people are leaving cocoa oil small-sized industries.

The fundamental problems faced in the development of cocoa oil small-sized industries in both agropolitan areas are quite complex, including; lack of production quantity, low labor absorption, low production continuity, and weak bargaining position of industry players in the available market (Zaid et al, 2018). This problem is caused by several things, namely; the lack of understanding of the actors of cocoa oil small-sized industries towards the mechanism of management and good industrial governance, support from other parties involved is still low, and there is no linkage between input-process-output from this industry, so based on conditions Therefore, it is very necessary to take steps to develop cocoa oil small-sized industries through empowerment mechanism based on management perspective such as; institutional and partnership so that the industry can provide economic added value for industry players (Zaid et al, 2017).

For this reason, this research was conducted by focusing on empowering cocoa oil small-sized industries through the exploration of the problems encountered, and formulating solutions for developing cocoa oil small-sized industries in the form of an industrial empowerment model design based on a business management perspective. In order to be more applicable to the design of the empowerment model of cocoa oil small-sized industries, a study was conducted using a qualitative approach through participatory data collection involving all relevant stakeholders.

Originality in this research is to try to explore the problems faced by the industry's small-sized cocoa oil in a participatory manner, then try to formulate a solution through the design of a small-sized industrial cocoa oil empowerment model in order to increase industrial added value by using a research approach qualitative.

\section{Literature Review}

Empowerment is a form of sharing power or moving power, participative management, and job enrichment (Gazzoli et al, 2010). Empowerment is a construct that links the strengths and competencies of individuals and organizations with environmental change, social policy and social change (Perkins and Zimmerman, 1995).

Empowerment can be a combination of several disciplines, among others; community development, psychology, management, organization, economics, education, etc., and is the link between individuals and organizations (Page and Czuba, 1999; Christens, 2012).

In theory, empowerment can be divided into two components, that is; individuals empowerment, and group empowerment (Adam, 1996), so that empowerment has a close relationship to the climate of an organization (Seibert et al, 2004). Group empowerment is a form of empowerment of all elements within a group, institution, or organization . The purpose of empowerment in an organization is to form an organization to become independent (Sulistyani, 2004).

The empowerment process can be carried out through three stages, namely; initiation, participatory, and emancipatory (Suryono, 2008). The initiation stage is the stage where the group or organization initiates an empowerment to find a way out of a problem faced; participatory stage is the stage where all the relevant parties in a group or organization jointly seek a solution to the problem at hand; and the emancipatory stage is the stage where all individuals in a group or organization, including women work together in implementing empowerment. Empowerment needs to be evaluated for results.

The empowerment evaluation process focuses on the involvement of all organizational components, including individuals, management, related internal parties (Fetterman, 1994; Fetterman, 2001; Petterman and Wandersman, 2005).

\section{Methodology}

This research was carried out on cocoa oil small-sized industries in the Agro-Metropolitan Area of Lanipa Valley and Rawa Tindondo in Southeast Sulawesi Province of Indonesia. This study uses a qualitative approach in exploring problems and developing empowerment model designs in the development of cocoa oil small-size industry. Exploration issues and empowerment models are prepared with reference to the perspective of business management, namely; perspective of raw materials, production, human resources and institutional, financial, and marketing. The informants used in this study consisted of; cocoa farmers as suppliers of raw materials, industry players, governments, investors, and large industries. Data collection techniques were carried out through indepth interview techniques, participatory appraisal, and focus group discussions (FGD). The analysis technique uses qualitative data analysis with Nvivo 12 Plus software.

Stages of analysis are carried out through several stages, namely; (1) conduct analysis based on data collected through participatory appraisal techniques. This analysis is carried out to find out and understand in depth the real conditions faced by cocoa oil small- 
sized industries. Participatory appraisal technique is used so that researchers together with the actors of cocoa oil small-sized industries can understand deeply related to what factors are the fundamental problems in the development of cocoa oil small-sized industries. This is considered important so that the formulation of development solutions to be prepared can be right on target; (2) conduct analysis based on data collected through focus group discussion (FGD) techniques. At this stage, the analysis is carried out to gather the aspirations of all interested parties, including; raw materials supplier; small-sized industries cocoa oil players; collector trader; wholesalers; government; research institutions; capital guarantee institutions; and other related parties. In the FGD, the data collected includes data related to the constraints faced, problem solutions, as well as the components needed in implementing the development solution design.

\section{Findings}

The results of this study provide information related to 2 (two) things, namely; (1) the results of the exploration of problems faced by cocoa oil small-sized industries; and (2) design of the empowerment model and the development of cocoa oil small-sized industries. The results of data analysis with Nvivo 12 Plus software regarding the exploration of problems faced by cocoa oil smallsized industries (data obtained through in-depth interviews and participatory appraisal techniques), can be seen in Figure 1.

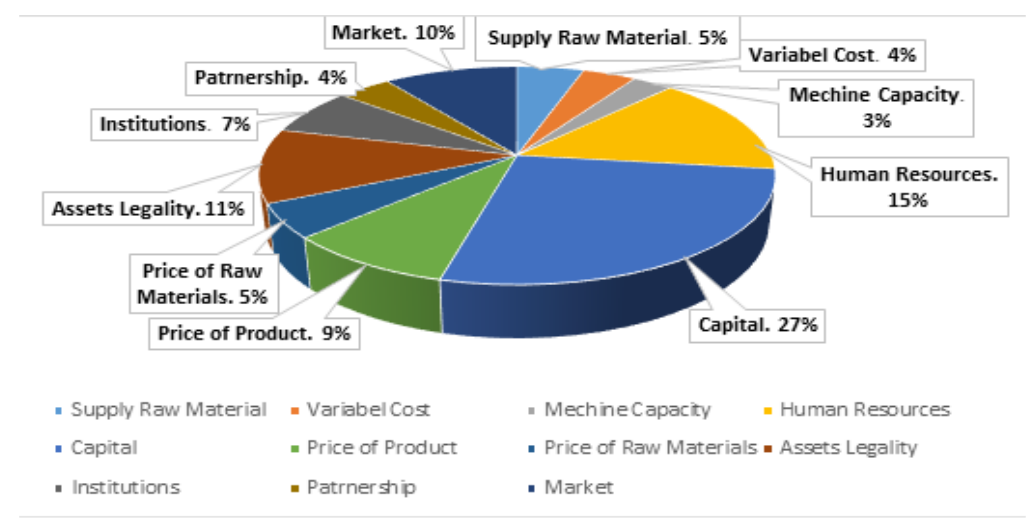

Figure 1: Exploring Problem of Cocoa Oil Small-sized Industries

Based on the results of data analysis in figure 1 shows that there are 11 (eleven) fundamental problems faced by cocoa oil smallsized industries, namely.

Supply of raw materials; This problem arises due to the high export sales of cocoa beans, which causes the supply of cocoa beans to the local cocoa oil industry to be small. This condition is considered unfavorable because it does not provide added value and directly impacts the low absorption of local labor.

Price of raw materials; this problem arises because suppliers of raw materials set prices based on export prices. The intended export price is the price at the level of collectors and large traders, so this has an impact on the low business margins received by cocoa oil small-sized industries.

High variable costs; this problem arises because the auxiliary materials used in industry are not available in the local market, consequently the auxiliary materials must be purchased from outside the area at a high price. The high cost of supporting materials is due to the high transportation costs considering the location of small-sized industries cocoa oil is quite far from the trade area;

Low mechine capacity; this problem arises due to the use of a cocoa oil processing machine with a very small capacity, this causes limited production of cocoa oil. The machine used by cocoa oil small-sized industries is a home industry-based machine that has a small production capacity. The replacement of machines with high production capacity has not been done because the price of the machine is quite high.

Low human resource skills; the level of education and skills possessed by the workforce is still relatively low, both in terms of technical and management, this is due to the lack of types of training that have been attended by workers. The government has facilitated the implementation of the training, but the frequency of training is still very limited so that the perpetrators of cocoa oil small-sized industries have not been fully able to absorb the training material provided.

Limited capital; this problem arises due to the weak access of industry players to existing capital institutions, this has an impact on low productivity and business margins. Weak access to cocoa oil small-sized industries players in capital institutions is also caused by their lack of knowledge regarding the procedures for submitting capital assistance to capital institutions. 
The role of business institutions that is not optimal; the existence of small-sized industries cocoa oil business groups have not played a maximal role in increasing industrial value added, this is due to the fact that these business groups are not well-managed and not yet based on entrepreneurship. This occurs due to the lack of knowledge of cocoa oil small-sized industries actors in the management of business groups and they do not yet know about the benefits that can be obtained from the existence of business groups;

Low product prices; the selling price of cocoa oil products at the industry level is classified as very low, this is because the target market is limited to only 2 (two) large traders, so that conditions often occur where the price of cocoa oil products is determined by the buyer. This happens because the big traders buy cocoa oil products directly to each cocoa oil small-sized industries individually, causing their bargaining position to be low;

Limited market access; This problem arises due to the lack of the ability of industry players to access a wider market, this is due to the role of business groups that are not optimal, the lack of understanding of how to access markets, and the lack of support of information technology facilities;

Lack of asset legality; assets owned by the cocoa oil industry players tend not to have aspects of legality, such as; land assets that do not have a certificate, buildings that do not have a building permit, and businesses that do not have a business permit. This causes the value of the firm to be very low. In addition, this also resulted in low growth in the cocoa oil small-sized industries business;

Lack of partnership; cocoa oil small-sized industries that are in the research location do not yet have partner institutions that can function as business strengthening institutions, this is caused by industry players not understanding the functions of partner institutions. Partner institutions that are expected to be involved in efforts to increase added value for cocoa oil small-sized industries, are; research and development institutions, related government institutions, non-governmental organizations, investors, capital institutions, banks, and other related institutions.

The results of the exploration of the problems faced by cocoa oil small-sized industries, then the basic reference in the preparation of the design model of empowerment and development of cocoa oil small-sized industries. The technique of designing the model is done by first carrying out focus group discussions (FGD) in order to gather data that involves all stakeholders, namely, raw material suppliers, industry players, government, investors, and large industries. The results of data collection through FGD techniques are then analyzed using a qualitative approach through Nvivo 12 Plus software. The results of the design of the small-sized industries empowerment model for cocoa oil can be seen in Figure 2.

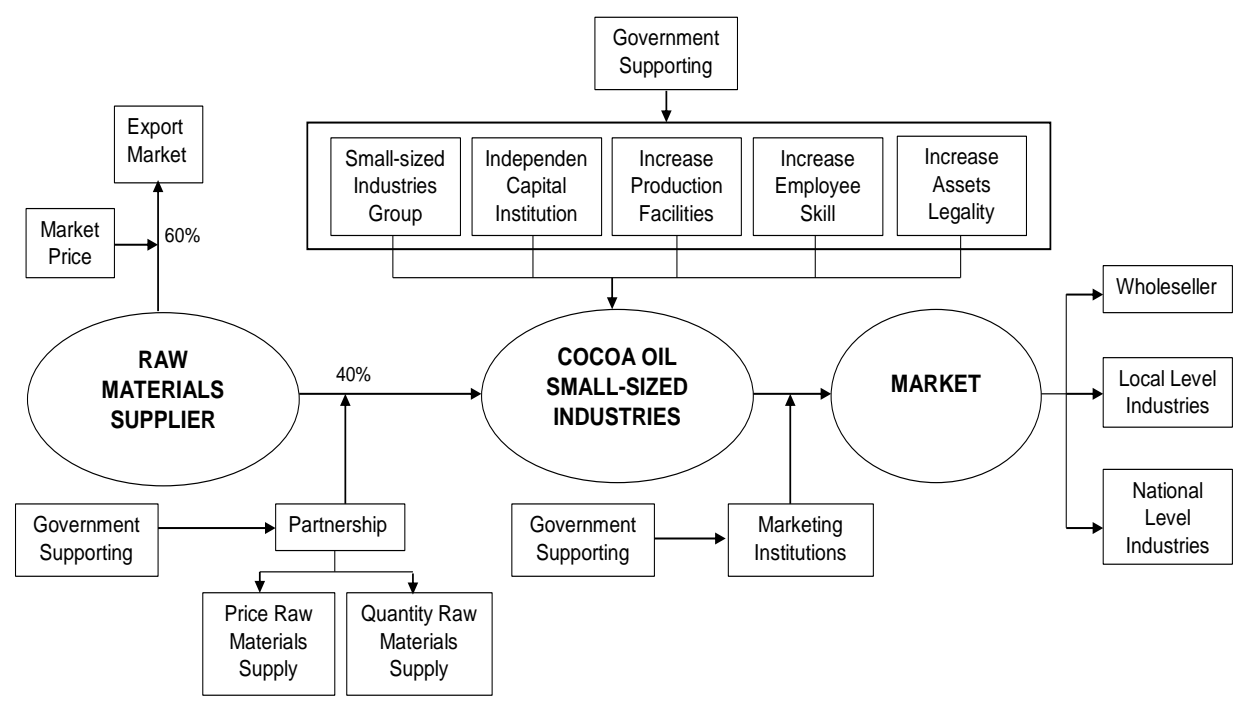

Figure 2: Empowerment Model of Cocoa Oil Small-sized Industries

Figure 2 explains that there are three main components in the design of the empowerment model of cocoa oil small-sized industries, namely, (a) raw material supplier; (b) small-sized industries cocoa oil; and (c) cocoa oil market. The relationship between raw material suppliers and cocoa oil small-sized industries is established in a form of partnership. This partnership formation is intended to increase the added value of the industry.

The partnership pattern is that raw material suppliers will allocate sales of cocoa beans to the export market by only $60 \%$ by referring to the prevailing price level in the market, while the remaining $40 \%$ will be allocated sales to cocoa oil small-sized industries with an agreed price level referring to in setting subsidized prices whose value is lower than market prices. This is carried out with the support of the government, especially related to the determination of subsidized prices. Furthermore, the relationship between cocoa oil small-sized industries and the market is also established through the formation of marketing institutions of cocoa oil small-sized industries. The establishment of marketing institutions is intended to increase market access. The government is expected to provide support to these marketing institutions by providing assistance in the form of; assistance, and assistance in marketing information 
technology facilities to improve the ability of cocoa oil small-sized industries to access larger potential markets, namely; whole seller, local level industries, and national level industries.

In the cocoa oil small-sized industries component, government support is needed in the form of:

Formation of small-sized industries group. The establishment of this business group aims to; increase production capacity, increase revenue, increase business development opportunities, and strengthen industrial structure. Government support in forming this business group is; provide assistance and control functions.

Establishment of an independent capital institution. This institution is a capital institution that was formed based on the results of self-help actors of cocoa oil small-sized industries. This institution can take the form of a cooperative business, where management and funding comes from the results of the group members' self-help. The establishment of this institution aims to overcome capital problems for cocoa oil small-sized industries. Government support in this case is to provide assistance and control functions.

Increasing production facility. The government is expected to be able to provide assistance in the form of production equipment for the perpetrators of cocoa oil small-sized industries. The intended production equipment is assistance in the form of production machinery, auxiliary materials, and packaging so that the quality and quantity of small-sized industries production of cocoa oil can be increased.

Increase employee skills. The government is expected to provide assistance in the form of education and training that is right on target. This is necessary so that the managerial capabilities of business people and workers can increase and have an impact on increasing productivity. In addition, it is also necessary to have education and training in the form of apprenticeships in similar industries that have been established in managerial management so that knowledge transfer can occur directly.

Increase assets legality. The government is expected to provide support in terms of legalizing ownership of the assets of small-sized industrial cocoa oil entrepreneurs. This meant that the business value could increase. Government support in this regard is to establish an independent institution whose job is to manage the legal aspects of the assets of cocoa oil small-sized industries. The government is also expected to formulate a regulation related to efforts to accelerate the processing of business licenses for cocoa oil small-sized industries.

\section{Discussion}

The empowerment model of cocoa oil small-sized industries to increase the added value of business in general emphasizes several important things, namely; a form of partnership is needed between the actors of cocoa oil small-sized industries and related parties, such as; government, raw material suppliers, and target markets. For this partnership to work well, government support is needed as a form of government support for small-sized industries.

In addition, government support is also expected in the form of providing assistance that is managerial both physical and nonphysical. Physically, government support is expected in the form of assistance to improve the availability of production facilities and infrastructure so that there will be effectiveness and efficiency in the implementation of the production process. Additionally, nonphysical aspects are also needed in the form of business assistance, implementation of targeted education and training, the creation of industrial business groups, the establishment of independent capital institutions, and the establishment of independent institutions whose job is to accelerate efforts to legalize assets and businesses for cocoa oil small-sized industries. In addition to requiring a form of partnership, so that the empowerment model of cocoa oil small-sized industries can increase added value, it also requires the existence of a supporting institution. This institution has a role to assist cocoa oil small-sized industries players in carrying out their operational activities, especially related to internal business activities. The supporting institutions that are expected to play a role in the application of this model are research and development institutions, capital assistance institutions, banks, non-governmental institutions, investors, and others.

\section{Conclusions}

Based on the results of research and discussion, then several things that can be concluded in this study are; (1) the results of the exploration of managerial perspectives that have become a problem in the development of cocoa oil small-sized industries, namely; supply raw materials; price of raw materials; variable costs; machine capacity; human resources; capital; institutional; product price; market access; assets legality; and partnership; (2) the design of the empowerment model of cocoa small-sized industries that was developed based on management perspective contains several important things, namely the need for a form of partnership between cocoa oil small-sized industries with other related parties such as; supplier of raw materials and target markets so that this empowerment effort can go well; and it is hoped that there will be government support in assisting managerial aspects both physical and non-physical in nature so that cocoa oil small-sized industries can increase the added value of their business.

The results of this study provide several implications for further research, namely; (a) research is needed aimed at designing model designs and partnership patterns between cocoa oil small-sized industries and raw material suppliers; (b) research is needed to design a market partnership model between cocoa oil small-sized industries and potential markets; and (c) research is needed aimed at 
evaluating the results of the application of the cocoa oil small-sized industries empowerment model that has been produced in this study in the next few years.

\section{References}

Adams, R. (1996). Social Work and Empowerment. Social Work and Empowerment. Macmillan Education UK. https://doi.org/10.1007/978-1-349-14033-6.

Bandur, A. (2019). Penelitian Kualitatif. Studi Multi-Disiplin Keilmuan dengan Nvivo 12 Plus. Mitra Wacana Media. Bogor.

BPS Sulawesi Tenggara. (2019). Provinsi Sulawesi Tenggara Dalam Angka 2019. Biro Pusat Statistik. Sulawesi Tenggara.

Christens, B. D. (2012). Toward Relational Empowerment. American Journal of Community Psychology, 50(1-2), 114-128. https://doi.org/10.1007/s10464-011-9483-5.

Elwina, Nafisah, \& Fachraniah. (2018). Ekstraksi Minyak Coklat dari Biji Kakao dengan Penambahan Jenis Pelarut. Proceeding $\begin{array}{llllll}\text { Seminar Nasional Politeknik Negri } \quad \text { Lhokseumawe, } & 2(1), & 72-76 . & \text { http://e- }\end{array}$ jurnal.pnl.ac.id/index.php/semnaspnl/article/download/747/713.

Fahrozi, D., Widayat, P. Heru., Sulaiman, I. (2018). Variasi Pasta dan Essence Kakao pada Proses Pembuatan Sabun Cair. Jurnal Ilmiah Mahasiswa Pertanian Unsyiah, 3(1), 340-344. http://www.jim.unsyiah.ac.id/JFP/article/view/6470/4889.

Fetterman, D. M. (1994). Empowerment evaluation. Evaluation Practice, 15(1), 1-15. https://doi.org/10.1016/0886-1633(94)900558.

Fetterman, D. M. (2001). Foundation of Empowerment Evaluation. Sage Publication Inc. London. https://books.google.co.id/books?hl=id\&lr=\&id=4XLGfIfxn94C\&oi=fnd\&pg=PP13\&dq=Foundation+of+Empowerment+ Evaluation.+Sage+Publication+Inc.+London.\&ots=SHIc5TZkM5\&sig=TOcdiHv6WIm5pL16cH357m9OhCA\&redir_esc= $\mathrm{y} \# \mathrm{v}=$ onepage $\& \mathrm{q}=$ Foundation $\% 20 \mathrm{of} \% 20$ Empowerment $\% 20$ Evaluation. \%20Sage \%20Publication\%20Inc.\%20London.\&f=f alse.

Fetterman, D. M \& Wandersman, A. (2005). Empowerment Evaluation Principles in Practices. Guillford Press. New York. https://books.google.co.id/books?hl=id\&lr=\&id=fzp4V_9HyAwC\&oi=fnd\&pg=PA155\&dq=Empowerment+Evaluation+P rinciples+in+Practices.+Guillford+Press.+New+York\&ots=ryIJJE2bYK\&sig=V630LFKpc75WVmUX4ukl-

ovZrTo\&redir_esc=y\#v=onepage\&q=Empowerment\%20Evaluation\%20Principles\%20in\%20Practices.\%20Guillford\%20P ress. $\% 20$ New\% 20 York \&f=false.

Gazzoli, G., Hancer, M., \& Park, Y. (2010). The role and effect of job satisfaction and empowerment on customers' perception of service quality: A study in the restaurant industry. Journal of Hospitality and Tourism Research, 34(1), 56-77. https://doi.org/10.1177/1096348009344235.

Page, N., and Czuba, E.C. (1999). Empowerment: What Is?. Journal of Extention. 37(5), 1-5. https://www.joe.org/joe/1999october/comm1.php/comm2.php.

Perkins, D. D., \& Zimmerman, M. A. (1995). Empowerment theory, research, and application. American Journal of Community Psychology, 23(5), 569-579. https://doi.org/10.1007/BF02506982.

Seibert, S. E., Silver, S. R., \& Randolph, W. A. (2004). Taking empowerment to the next level: A multiple-level model of empowerment, performance, and satisfaction. Academy of Management Journal, 47(3), 332-349. https://doi.org/10.2307/20159585.

Sulistyani, A. T. (2004). Kemitraan dan Model-Model Pemberdayaan. IKAPI. Yogyakarta.

Suryono, A \& Trilaksono, N. (2008). Paradigma, Model, Pendekatan Pembangunan, dan Pemberdayaan Masyarakat di Era Otonomi Daerah. Bayumedia Publishing. Malang. https://scholar.google.co.id/scholar?lookup=0\&q=Paradigma,+Model,+Pendekatan+Pembangunan,+dan+Pemberdayaan+ Masyarakat+di+Era+Otonomi+Daerah.+Bayumedia+Publishing.+Malang.\&hl=id\&as_sdt=0,5.

Zaid, S. (2016). Study on Increasing Local Competitiveness of Superior-based Commodity in Southeast Sulawesi. JAM Bisnis MM UHO, 6(1), 77-85.

Zaid, S., Syaefuddin, D. T \& Halim. (2017). The Development of Cocoa Oil Industry Chain Value Model to Increase Sustainable Additional Value. IOSR Journal of Business and Management, 19(7), 1-12. https://doi.org/10.9790/487X-1907020112.

Zaid, S., Syaefuddin, D. T \& Halim. (2018). The Innovation of Value Chain Model of Cocoa Oil Industry to Increase Sustainable Value Added. International Journal of Scientific \& Engineering Research, 9(3), 1891-1902. https://www.ijser.org/onlineResearchPaperViewer.aspx?The-Innovation-of-Value-Chain-Model-of-Cocoa-Oil-Industry-toIncrease-The-Sustainable-Value-Added.pdf. 